\title{
Develop and evaluate the effectiveness of guidelines on prevention and home care management of opportunistic infections in terms of knowledge of caretakers of HIV/AIDS patients
}

\author{
Vandna Pandey ${ }^{1}$, Aashish Parihar ${ }^{2}$,Himanshu Vyas ${ }^{3}$, Naveen Kumar Sharma ${ }^{4}$ \\ 1, 2, 3, 4 Nursing tutor, College of Nursing, AIIMS, Jodhpur
}

\begin{abstract}
The objective of the study were to develop the guidelines for caretakers of HIV/AIDS patients on prevention and home care management of opportunistic infections; evaluate the effectiveness of guidelines on prevention and home care management of opportunistic infections for caretakers of HIV/AIDS patients before and after administration of guidelines in terms of knowledge of caretakers; seek the association of post test knowledge scores of caretakers on prevention and home care management of opportunistic infections with selected demographic factors; determine the acceptability and utility of guidelines on prevention and home care management of OIs by the care-takers of HIV/AIDS patients. An evaluative research approach with one group pre-test post-test design was adopted for the study. The study was conducted in Ram Manohar Lohia Hospital, New Delhi. The sample consisted of 60 caretakers of HIV/AIDS patients selected by purposive sampling. The tools used were structured interview scheduled and a structured opinionnaire. Guidelines were developed for enhancing the knowledge of caretakers regarding prevention and home care management of opportunistic infections among HIV/AIDS patients The data obtained were analyzed using both inferential and descriptive statistics. The major findings of the study were that the mean post-test knowledge scores were higher than mean pre-test knowledge scores of caretakers indicating that the guidelines were effective in increasing the knowledge of caretakers regarding prevention and home care management of opportunistic infections among HIV/AIDS patients. There was significant association of post-test knowledge scores of caretakers regarding prevention and home care management of OIs with selected factors - age, sex, educational qualification, marital status, occupation, family Income. The structured opinionnaire revealed that the guidelines on prevention and home care management of OIs were acceptable and useful for the caretakers.
\end{abstract}

Key Words: guidelines, prevention and home care management, opportunistic infections, caretakers, knowledge, HIV/AIDS patients.

\section{Introduction}

Acquired Immuno Deficiency Syndrome (AIDS) was first recognized among the homosexual men in the west coast of America. The first case of HIV (Human Immune Deficiency Virus) in India was diagnosed among commercial sex worker in Chennai in 1986. In India, the estimated number of HIV infections as of 2008 is 2.47 million. The distribution of HIV infection and mode of transmission varies by state. Most HIV infections in India (86\% of reported AIDS cases) are due to unprotected heterosexual transmission (UNAIDS, 2008 Report on Global AIDS Epidemic). Information from person tested positive for HIV at the Integrated Counseling and Testing centers across the country during 2009-2010 shows that $87.1 \%$ of HIV infections are still occurring through heterosexual route of transmission. While parent to child transmission accounts for $5.4 \%$ of HIV cases detected, Injecting drug use $1.6 \%$, Men who have sex with Men $1.5 \%$ and contaminated blood and blood products account for $1 \%$. (NACO annual reports 2010-11). Globally there were estimated 33 million people infected with HIV in 2007 with 2.27 million new infections and 2 million HIV related deaths. Nearly an estimated 5 million people infected with HIV lived in Asia in 2007 and about 3, 80,000 people were newly infected (2008 UNAIDS Global Epidemic Update). At present, India, which has 2.47 million HIV patients, ranks third after South Africa and Nigeria, and her prevalence rate is $0.31 \%$. India recorded 18,000 pediatric HIV births of 65,000 HIV +ve mothers. (AIDS epidemic report, 2010).

India is one of the largest and most populated countries in the world, with over 1billion inhabitants. Of this number, it is estimated (2008) that around 2.27 million people are currently living with HIV, which equates to a prevalence of $0.29 \%$. With a population around a billion, a mere $0.1 \%$ increase in HIV prevalence would increase the estimated number of people living with HIV by over half a million. (NACO annual report 20092010). HIV prevalence tends to be higher in the industrialized and peninsular states. The six states with the highest HIV prevalence are: Maharashtra, Andhra Pradesh, Tamil Nadu, Karnataka, Manipur, and Nagaland. 


\section{OPPORTUNISTIC INFECTIONS AMONG PATIENTS WITH AIDS IN INDIA}

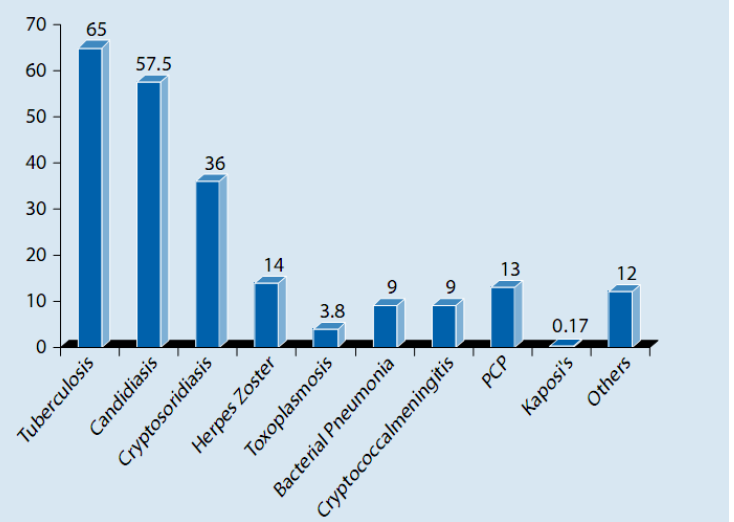

A total of 51,818 people in Delhi have been infected by HIV/AIDS (NACO annual report 2010-11)

Opportunistic infections (OIs) influence the morbidity and mortality due to HIV infections. Data from India on the incidence of OIs among HIV-infected individuals by stages of immunodeficiency are scarce. The high incidence of commonly reported OIs in Indian HIV-infected individuals highlights the need for early screening and also the need to increase awareness in healthcare providers, in order to improve decisions regarding prophylaxis for prevention and appropriate therapeutic intervention. Emphasis needs to be given to the early diagnosis and management of tuberculosis in HIV-infected individuals.(Manisha Ghate et al. 2008). The human immunodeficiency virus (HIV) infection leading to Acquired Immunodeficiency Syndrome (AIDS) causes progressive decline in immunological response in people living with HIV/AIDS (PLWHA) making them susceptible to a variety of opportunistic infections which are responsible for morbidity and mortality. The pattern of opportunistic infections in people living with HIV/AIDS (PLWHA) attending Community care centre (CCC) was studied. The presenting symptoms were fever (82.2\%), weight loss $(65.8 \%)$, cough \& dyspnoea $(45.5 \%)$ and diarrhea $(41.7 \%)$. One or more opportunistic infections were observed in 63 patients $(57 \%)$. Commonly observed were pulmonary tuberculosis $(52.3 \%)$, candidiasis (39\%), cryptosporidial diarrhea $(30.1 \%)$ and Pneumocystis Carinii Pneumonia (PCP) (14.2\%). In 46.4\% of cases CD4 count was less than 200. Findings point to the importance of early diagnosis and treatment of opportunistic infections in order to improve quality and expectancy of life. (Anant A. Takalkar et al. 2012).

Numbers of studies have been conducted on HIV\AIDS patients and also on prevalence of opportunistic infections among them. But very few studies are conducted in India. Hence the need was felt by the investigator to take a study to develop guidelines for the caretakers of HIV/AIDS patients on prevention and home care management of OIs and enhance their knowledge regarding prevention and home care management of OIs in HIV patient.

Objectives of the study were to develop the guidelines for caretakers of HIV/AIDS patients on prevention and home care management of opportunistic infections; To evaluate the effectiveness of guidelines on prevention and home care management of opportunistic infections for caretakers of HIV/AIDS patients before and after administration of guidelines in terms of knowledge of caretakers; To seek the association of post test knowledge scores of caretakers on prevention and home care management of opportunistic infections with selected factors i.e. Age, Sex, Educational Qualification, Marital status, Occupation and Family Income; and To determine the acceptability and utility of guidelines on prevention and home care management of OIs by the caretakers of HIV/AIDS patients.

In the present study, the dependent variable is the knowledge scores of caretakers regarding prevention and home care management of opportunistic infections and independent variable is guidelines for caretakers on prevention and home care management of opportunistic infections.

For present study evaluative research approach was thought to be most appropriate to achieve the objectives of present study. The research design selected for the present study was a Pre-experimental "one group pre-test post-test design" and study was conducted in ART Centre, RML Hospital, New Delhi. Sample for the present study comprises of the caretakers of HIV/AIDS patients and a purposive sampling was used to select 60 subjects for the study.

A structured interview schedule was constructed to assess the knowledge of the caretakers on prevention and home care management of OIs. The reliability of the tool was found by administering the tool to 15 caretakers. KR-20 was used to compute the reliability of structured interview schedule and was found to be 0.83 . An opinionnaire was also developed to know the acceptability and utility of guidelines by caretakers. Cronbach alpha was used to compute the reliability of structured opinionnaire and was found to be 0.93 which was reliable. 
A structured knowledge interview schedule was prepared based on review of research and non-research literatures and opinion of experts. The structured interview schedule consisted of two parts i.e. Part-I and Part-II. Part I consisted of 14 items seeking informations on background data. Part II consisted of 26 knowledge items. The maximum score on the structured knowledge interview schedule was 26. (One mark for each correct answer and zero mark for each incorrect answer). Researcher also developed a guideline for the caretakers on prevention and home care management of OIs. Guideline covers the Concept of HIV/AIDS; Causes of HIV/AIDS; Who can get HIV infection; Introduction of opportunistic infections; Common types of OIs e.g. tuberculosis, pneumonia, candidiasis, gastrointestinal infections etc ; Prevention and home care management of common types of OIs; Simple preventive measures to minimize chances of getting OIs.

RESULT: The data were analyzed and interpreted using descriptive and inferential statistics. The data analyses have been organized under three Sections. Section-I :Description of sample characteristics; Section- II :Findings related to evaluation of effectiveness of the guidelines in terms of knowledge of caretakers of HIV/AIDS patients regarding prevention and home care management of OIs; Section- III :Findings related to association of post-test knowledge scores of caretakers regarding prevention and home care management of OIs with selected factors; Section-IV: Findings related to the acceptability and utility of the guidelines on prevention and home care management of OIs by caretakers.

\section{SECTION I \\ DESCRIPTION OF SAMPLE CHARACTERISTICS}

TABLE 1

Frequency and percentage distribution of caretakers by their sample characteristics

\begin{tabular}{|c|c|c|c|}
\hline S.No & Characteristics & Frequency & $\%$ \\
\hline \multirow{5}{*}{1} & Age & & \\
\hline & $18-25$ & 10 & 17 \\
\hline & $26-33$ & 29 & 48 \\
\hline & $34-41$ & 11 & 18 \\
\hline & More than 42 & 10 & 17 \\
\hline \multirow{3}{*}{2} & Gender & & \\
\hline & Male & 35 & 58 \\
\hline & Female & 25 & 42 \\
\hline \multirow{6}{*}{3} & Religion & & \\
\hline & Hindu & 36 & 60 \\
\hline & Muslim & 10 & 17 \\
\hline & Sikh & 4 & 7 \\
\hline & Christian & 9 & 15 \\
\hline & Any other & 1 & 2 \\
\hline \multirow{4}{*}{4} & Marital status & & \\
\hline & Married & 42 & 70 \\
\hline & Unmarried & 12 & 20 \\
\hline & Widow /Divorcee & 6 & 10 \\
\hline \multirow{5}{*}{5} & Education qualification & & \\
\hline & Secondary school & 35 & 58 \\
\hline & Higher secondary & 12 & 20 \\
\hline & Graduation & 10 & 17 \\
\hline & Post Graduation and above & 3 & 5 \\
\hline \multirow{5}{*}{6} & Family income per month & & \\
\hline & Less than $5,000 /-$ & 20 & 33 \\
\hline & $6,000 /-$ to $10,000 /-$ & 22 & 37 \\
\hline & $11,000 /-$ to $20,000 /-$ & 10 & 17 \\
\hline & More than $20,000 /-$ & 8 & 13 \\
\hline \multirow{7}{*}{7} & Occupation & & \\
\hline & Govt job & 15 & 25 \\
\hline & Private job & 18 & 30 \\
\hline & Business & 8 & 13 \\
\hline & Retired/not working & 2 & 3 \\
\hline & Housewife & 16 & 27 \\
\hline & Any other & 1 & 2 \\
\hline \multirow{3}{*}{8} & Residential Status & & \\
\hline & Rural & 32 & 53 \\
\hline & Urban & 28 & 47 \\
\hline \multirow{3}{*}{9} & Family Type & & \\
\hline & Joint family & 23 & 38 \\
\hline & Extended family & 10 & 17 \\
\hline
\end{tabular}


Develop and evaluate the effectiveness of guidelines on prevention and home care management of

\begin{tabular}{|c|c|c|c|}
\hline & Nuclear Family & 27 & 45 \\
\hline \multirow{6}{*}{10} & $\begin{array}{l}\text { Number of member Infected with HIV / } \\
\text { AIDS in the family }\end{array}$ & & \\
\hline & One & 12 & 20 \\
\hline & Two & 32 & 53 \\
\hline & Three & 10 & 17 \\
\hline & Four & 6 & 10 \\
\hline & More than four & 0 & 0 \\
\hline \multirow{5}{*}{11} & Relationship with the patient & & \\
\hline & Brother/Sister & 8 & 13 \\
\hline & Mother/ Father & 10 & 17 \\
\hline & Husband/ Wife & 38 & 63 \\
\hline & Any other & 4 & 7 \\
\hline \multirow{3}{*}{12} & $\begin{array}{l}\text { Knowledge regarding prevention and care of } \\
\text { OIs in HIV/AIDS patients }\end{array}$ & & \\
\hline & Yes & 34 & 57 \\
\hline & No & 26 & 43 \\
\hline \multirow{5}{*}{13} & $\begin{array}{l}\text { Health care facility available/utilized in their } \\
\text { locality }\end{array}$ & & \\
\hline & Health center & 5 & 8 \\
\hline & Hospital & 36 & 60 \\
\hline & Private practitioner & 17 & 28 \\
\hline & Any other & 2 & 3 \\
\hline \multirow{6}{*}{14} & Information regarding referral services & & \\
\hline & Newspaper & 1 & 2 \\
\hline & Television & 1 & 2 \\
\hline & Friends/ Relatives & 44 & 73 \\
\hline & Health fares/Camps & 10 & 17 \\
\hline & Others & 4 & 7 \\
\hline
\end{tabular}

\section{SECTION II}

FINDINGS RELATED TO EVALUATION OF EFFECTIVENESS OF THE GUIDELINES IN TERMS OF KNOWLEDGE OF CARETAKERS OF HIV/AIDS PATIENTS REGARDING PREVENTION AND HOME CARE MANAGEMENT OF OIS.

TABLE-2

Range of scores, Mean, median and standard deviation of pre-test and post-test knowledge scores of caretakers.

\begin{tabular}{|l|c|c|c|c|}
\hline \multicolumn{5}{|c|}{$\mathrm{N}=60$} \\
\hline Knowledge test & Range of scores & Mean & Median & SD \\
\hline Pre-test & $7-13$ & 10.63 & 11 & 1.44 \\
\hline Post-test & $18-21$ & 18.88 & 18.5 & 0.91 \\
\hline
\end{tabular}

Maximum possible score $=60$

\section{SECTION- III}

FINDINGS RELATED TO ASSOCIATION OF POST-TEST KNOWLEDGE SCORES OF CARETAKERS REGARDING PREVENTION AND HOME CARE MANAGEMENT OF OIS WITH SELECTED FACTORS

TABLE 3

Chi-square value showing association of post-test knowledge scores of caretakers and selected factors.

$\mathrm{N}=60$

\begin{tabular}{|c|c|c|c|c|c|c|c|c|}
\hline \multirow{2}{*}{ S.no } & \multirow{2}{*}{$\begin{array}{l}\text { Selected } \\
\text { factors }\end{array}$} & \multicolumn{3}{|c|}{ Knowledge score } & \multirow{2}{*}{$\begin{array}{l}\text { Chi } \\
\text { Square }\end{array}$} & \multirow{2}{*}{ Table } & \multirow{2}{*}{$\mathrm{df}$} & \multirow{2}{*}{$\begin{array}{c}\text { significant } / \text { not } \\
\text { significant at } 0.05 \\
\text { level of significance }\end{array}$} \\
\hline & & Below median & & Above median & & & & \\
\hline \multirow{5}{*}{1} & Age & & & & \multirow{5}{*}{56.61} & \multirow{5}{*}{7.815} & \multirow{5}{*}{3} & \multirow{5}{*}{ Significant } \\
\hline & $18-$ & & 4 & 6 & & & & \\
\hline & $26-$ & & 13 & 16 & & & & \\
\hline & $34-$ & & 5 & 6 & & & & \\
\hline & above & & 4 & 6 & & & & \\
\hline \multirow{3}{*}{2} & Sex & & & & \multirow{3}{*}{11.69} & \multirow{3}{*}{3.841} & \multirow{3}{*}{1} & \multirow{3}{*}{ Significant } \\
\hline & Male & & 15 & 20 & & & & \\
\hline & Female & & 11 & 14 & & & & \\
\hline \multirow{2}{*}{3} & Marital s & & & & \multirow{2}{*}{111.88} & \multirow{2}{*}{5.991} & \multirow{2}{*}{2} & \multirow{2}{*}{ Significant } \\
\hline & Married & & 15 & 27 & & & & \\
\hline
\end{tabular}




\begin{tabular}{|c|c|c|c|c|c|c|c|}
\hline & Unmarried & 6 & 6 & & & & \\
\hline & Divorcee/widow & 5 & 1 & & & & \\
\hline \multirow{5}{*}{4} & \multicolumn{3}{|c|}{ Educational qualification } & \multirow{5}{*}{95.81} & \multirow{5}{*}{7.815} & \multirow{5}{*}{3} & \multirow{5}{*}{ Significan } \\
\hline & Secondary & 11 & 24 & & & & \\
\hline & higher sec & 7 & 5 & & & & \\
\hline & Graduate & 5 & 5 & & & & \\
\hline & Post Graduate. & 3 & 0 & & & & \\
\hline \multirow{5}{*}{5} & Family income pe & & & \multirow{5}{*}{35.67} & \multirow{5}{*}{7.815} & \multirow{5}{*}{3} & \multirow{5}{*}{ Significan } \\
\hline & $<5,000 /$ & 7 & 13 & & & & \\
\hline & $6,000-10,000$ & 10 & 12 & & & & \\
\hline & $11,000-20,000$ & 5 & 5 & & & & \\
\hline & $>20,000 /-$ & 5 & 3 & & & & \\
\hline \multirow{7}{*}{6} & Occupation & & & \multirow{7}{*}{276.18} & \multirow{7}{*}{11.07} & \multirow{7}{*}{5} & \multirow{7}{*}{ Significan } \\
\hline & Govt job & 9 & 6 & & & & \\
\hline & Pvt job & 11 & 7 & & & & \\
\hline & Business & 1 & 7 & & & & \\
\hline & Retired/not working & 0 & 2 & & & & \\
\hline & Housewife & 5 & 11 & & & & \\
\hline & Other & 0 & 1 & & & & \\
\hline
\end{tabular}

\section{SECTION-IV}

\section{FINDINGS RELATED TO THE ACCEPTABILITY AND UTILITY OF THE GUIDELINES ON PREVENTION AND HOME CARE MANAGEMENT OF OIS BY CARETAKERS.}

TABLE 4

Obtained range of scores,mean and standard deviation of acceptability and utility scores of guidelines by caretakers

\begin{tabular}{|c|c|c|c|}
\hline Group & Obtained range of score & Mean & SD \\
\hline Caretakers & $22-30$ & 26.25 & 2.14 \\
\hline
\end{tabular}

Maximum possible score $=30$

TABLE 5

Frequency and percentage distribution of responses of caretakers regarding acceptability and utility of the guidelines

\begin{tabular}{|c|c|c|c|c|c|c|c|}
\hline & \multicolumn{7}{|c|}{$\mathrm{N}=60$} \\
\hline S.NO & STATEMENT & $\begin{array}{l}\text { To a great } \\
\text { extent (3) }\end{array}$ & $\%$ & $\begin{array}{r}\text { To some } \\
\text { extent }(2)\end{array}$ & $\%$ & $\begin{array}{l}\text { Not at } \\
\text { all }(1)\end{array}$ & $\%$ \\
\hline 1 & $\begin{array}{l}\text { I believe that I can learn much from this } \\
\text { guidelines }\end{array}$ & 45 & 75 & 15 & 25 & 0 & 0 \\
\hline 2 & $\begin{array}{l}\text { I find that this guidelines provides information } \\
\text { which is beneficial }\end{array}$ & 34 & 56.67 & 26 & 43.3 & 0 & 0 \\
\hline 3 & $\begin{array}{l}\text { I find that the different aspects of this } \\
\text { guidelines are of practical use to me in caring } \\
\text { AIDS patient }\end{array}$ & 39 & 65 & 21 & 35 & 0 & 0 \\
\hline 4 & $\begin{array}{l}\text { I find that the language of guidelines is easy } \\
\text { and simple }\end{array}$ & 36 & 60 & 24 & 40 & 0 & 0 \\
\hline 5 & $\begin{array}{l}\text { I feel that the guidelines is adequate to } \\
\text { enhance knowledge regarding prevention \& } \\
\text { home care management of OIs. }\end{array}$ & 39 & 65 & 21 & 35 & 0 & 0 \\
\hline 6 & $\begin{array}{l}\text { I find that the guidelines has given me } \\
\text { knowledge about the preventive aspects of OIs } \\
\text { among patients having HIV/AIDS }\end{array}$ & 35 & 58.33 & 25 & 41.7 & 0 & 0 \\
\hline 7 & I find this is interesting and useful to read & 40 & 66.67 & 20 & 33.3 & 0 & 0 \\
\hline 8 & $\begin{array}{l}\text { I find Picture / illustration given in the } \\
\text { guidelines are appropriate and meaningful }\end{array}$ & 18 & 30 & 42 & 70 & 0 & 0 \\
\hline 9 & $\begin{array}{l}\text { I find that the guidelines can be used without } \\
\text { any body's help }\end{array}$ & 35 & 58.33 & 25 & 41.7 & 0 & 0 \\
\hline 10 & I would like to have a copy of this guidelines & 52 & 86.67 & 8 & 13.3 & 0 & 0 \\
\hline & TOTAL & 373 & 62.17 & 227 & 37.83 & & \\
\hline
\end{tabular}




\section{Discussion:}

Forty eight percent of caretakers were in the age group of 26-33yrs, where as $18 \%$ were in the age group of 34-41yrs and 17\% each comes under age group of 18-25 yrs and more than 42yrs. Fifty eight percent of the caretakers were male whereas $42 \%$ were female. Sixty percentages of the caretakers were Hindus, $17 \%$ were Muslims, $15 \%$ were Christians, $7 \%$ were Sikh and $2 \%$ were others. Majority of the caretakers $(70 \%)$ were married. Educational qualification of majority of caretakers $(58 \%)$ was secondary school passed. As regard to family income per month, $37 \%$ of caretakers had family income of Rs 6000-10,000 per month followed by $33 \%$ had less than Rs 5000, $17 \%$ caretakers had Rs 11,000-20,000 and 13\% caretakers had more than Rs 20,000 family income per month. About $30 \%$ caretakers were in private job, $27 \%$ were housewives, $25 \%$ were in government job, $13 \%$ were in business group, $3 \%$ belonged to retired/not working group and $2 \%$ belonged to other occupation. Regarding their residential status $53 \%$ belonged to rural area and $47 \%$ belonged to urban area. On an average of samples $45 \%$ belonged to nuclear family type, $38 \%$ belonged to joint family type and rest of them belonged to extended family type.

Further data indicated that about $53 \%$ of caretakers had been two members infected with HIV in the family followed by $20 \%$ had one member affected, $17 \%$ had three member affected and $10 \%$ had four member affected in the family with HIV. Regarding relationship with the patient, majority (63\%) of caretakers was related as husband-wife.

About their knowledge regarding prevention and care of OIs in HIV/AIDS patients more than half of the caretakers (57\%) had certain knowledge regarding prevention and care of OIs in HIV/AIDS patients and remaining 43\% did not have any knowledge regarding prevention and care of OIs in HIV/AIDS patients.

Sixty percentage of the sample were having hospital as health care facility available/ utilized in their locality, $28 \%$ were having private practitioner as health care facility, $8 \%$ had health center and $3 \%$ were having other health care facility available/ utilized in their locality. Seventy three percent of the caretakers were having information regarding referral services from their friends and relatives, $17 \%$ got this information from health fares and camps, $7 \%$ got this information from other sources and $2 \%$ each got information regarding referral services from newspapers and television.

The mean post -test knowledge scores was higher than the mean pre- test knowledge scores and was found to be statistically significant at 0.05 level of significance. There was significant association of post-test knowledge scores of caretakers with selected factors as the calculated chi-square values were significant at 0.05 level of significant. The guidelines on prevention and home care management of OIs of HIV/AIDS patients were found to be acceptable and useful for the caretakers.

\section{Implication}

The finding of the present study shows several implications for nursing practice, nursing education, nursing administration and nursing research.

NURSING PRACTICE: AS there are very less material available for the caretakers regarding the prevention and home care management of HIV/ AIDS patient, therefore there is the need to help the primary caretakers in preventing and managing the opportunistic infection among HIV patient. Nurses will create awareness among the target group and will bring down the incidence of OI among HIV/AIDS patients. It should be made available to nurses to serve as guide and to provide teaching to family in ART Centers.

NURSING EDUCATION: Every nursing student should be given opportunity to visit the ART centers and to participate in proving care to these patients. The nursing personnel working in ART center for AIDS patients should be given in- service education to update their knowledge in providing care to AIDS patient and preventing the occurrence of OI.

NURSING ADMINISTRATION: In service and continuing education on management of OI should be systematically planned and conducted for all nursing personnel so that they are able to identify the learning need of client and to plan, conduct and evaluate client teaching in different setting.

NURSING RESEARCH: There is a need to extend intensive nursing research in the area of education especially in that area where the feasibility of caretakers involvement in the care of patient with HIV using better method of teaching and effective teaching materials. A survey can be conducted to study the attitude of nurses regarding participation of family members in the prevention and management of OI in patient with HIV.

PUBLIC EDUCATION: The guideline on management of OI can be used effectively in making the public awareness about the disease and its management and prevention.

\section{Conclusion}

There was a deficit in knowledge regarding prevention and home care management of OI in HIV patient in selected group of caretakers; Guideline was effective in enhancing the knowledge of caretaker regarding prevention and home care management of OI in HIV patient; There was an association between post 
test knowledge score and selected factors like age, sex, marital status, family income, occupation and education; The guideline has high acceptability and utility among the caretaker.

\section{References}

[1]. Abdellah, F.G. and Levine, E. (1979). Better Patient Care through Nursing Research. $2^{\text {nd }}$ ed., New York: McMillan Publishing Company, 23-32.

[2]. Best and Khan. (2004) Research in Education. $7^{\text {th }}$. edition. New Delhi: Prentice Hall of India.

[3]. Campbel, Willam G. (1994). Form And Style In Thesis Writing. Boston: Houghton Mifflin Co.

[4]. David S. Lindsay and Louis M. Weiss (2004). Opportunistic Infections: Toxoplasma, Sarcocystis, and Microsporidia. Kulwer Academic Publisher.

[5]. Dhaulta, J and Kapur, S. (1997). Hand book for nurses on HIV/AIDS. New Delhi: Voluntary health association of India. Page no $1-52$

[6]. Facts sheets on HIV/AIDS for nurses and midwives. New Delhi: WHO publications. 2002 Page no 1-98

[7]. Ghate Manisha et. al. (2008). Incidence of common opportunistic infections in HIV-infected individuals in Pune, India: analysis by stages of immunosuppression represented by CD4 counts. National AIDS Research Institute.

[8]. Guidelines for nursing management of people infected with HIV. WHO publications, 1996, page 8-166

[9]. Hart, C. (2005). Doing Your Master's Dissertation. $1^{\text {st }}$ ed., New Delhi: Vistaas Publications.

[10]. HIV/AIDS: prevention, care \& control. New Delhi: NACO publications, 1996. Page no 18-38

[11]. NACO. (1992). Prevention of transmission of HIV in hospitals.

[12]. NACO. (2010-11).Annual report. Government of India, New Delhi

[13]. NACO \& INC. (2009) HIV/AIDS and ART training for Nurses. New Delhi, Page no. 9-130

[14]. NACO \& INC. (2009), Facilitator's Guide. New Delhi. Page no.202-22

[15]. Aggarwal, I. et al. Evidence for onward transmission of HIV - 1 non - B subtype strains in the United Kingdom. Journal of Acquired Immune Deficiency Syndrome. 2006, 41(2), page no 201-209.

[16]. Chakraborty, Nilanjan et.al. (2010). Incidence of multiple Herpesvirus infection in HIV seropositive patients, a big concern for Eastern Indian scenario, Virology Journal. 147(7), Page No. 343-348

[17]. Chhin Senya et.al.(2003). Spectrum of opportunistic infections in hospitalized HIV-infected patients in Phnom Penh, Cambodia, Royal Society of Medicine Press Limited. 14(6), Page No.411-416

[18]. Correa M and Gisselquist D (2006). Routes of HIV transmission in India: assessing the reliability of information from AIDS case surveillance, Int Journal of STD AIDS. 17(11), Page No.731-735

[19]. Kuruswamy N et. al.(1995). Spectrum of opportunistic infections among AIDS patients in Tamil Naidu, India, Int J Sex Transm Dis AIDS. 92(6), Page No.447-449

[20]. http://aids-clinical-care.jwatch.org/cgi/content/full/2009/622/1

[21]. http://ijsa.rsmjournals.com/content/14/6/411.abstract

[22]. http://www.ajol.info/index.php/bajopas/article/viewFile/58466/46811. 